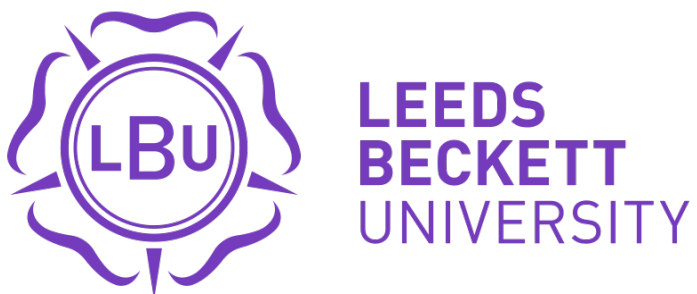

Citation:

Bianchini, F and Ghilardi, L (2007) Thinking culturally about place. Place Branding and Public Diplomacy, 3 (4). 280 - 286. ISSN 1751-8040 DOI: https://doi.org/10.1057/palgrave.pb.6000077

Link to Leeds Beckett Repository record:

https://eprints.leedsbeckett.ac.uk/id/eprint/552/

Document Version:

Article (Accepted Version)

The aim of the Leeds Beckett Repository is to provide open access to our research, as required by funder policies and permitted by publishers and copyright law.

The Leeds Beckett repository holds a wide range of publications, each of which has been checked for copyright and the relevant embargo period has been applied by the Research Services team.

We operate on a standard take-down policy. If you are the author or publisher of an output and you would like it removed from the repository, please contact us and we will investigate on a case-by-case basis.

Each thesis in the repository has been cleared where necessary by the author for third party copyright. If you would like a thesis to be removed from the repository or believe there is an issue with copyright, please contact us on openaccess@leedsbeckett.ac.uk and we will investigate on a case-by-case basis. 


\title{
THINKING CULTURALLY ABOUT PLACE
}

\author{
Think Piece in: Place Branding and Public Diplomacy \\ Vol.3, Number 4, October 2007, ISSN 1751-8040, Palgrave journals.
}

Franco Bianchini and Lia Ghilardi

\begin{abstract}
:
This article explains the bases for an alternative approach to place branding and marketing, based on the disciplines of Cultural Mapping and Cultural Planning. After an introduction of key cultural mapping and planning concepts and issues, the article discusses some innovative practical examples of culturally sensitive place branding and marketing from Sweden and the UK, and concludes by outlining some components of a possible future agenda for action.
\end{abstract}

\section{Introduction}

The approach to place marketing proposed in this article starts from the assumption that it is impossible directly to transfer to a place approaches used for marketing products like cars, cheese or mineral water. Chris Murray's book Making Sense of Place: New Approaches to Place Marketing advocates the importance of an interdisciplinary and creative approach to understanding places as complex and multifaceted cultural entities (Murray, 2001). The book takes issue with the position of Philip Kotler, author of Marketing Places and one of the most influential authors in place marketing. Kotler writes that 'places are, indeed, products whose identities and values must be designed and marketed' (quoted in Murray 2001, 64). Murray concludes that 'the notion of designing identities for places should be rejected as in the end it leads to disaffection (...) and there is insufficient evidence that it works' (2001, 73).

Murray's proposal for an alternative to Kotler's designing of place identities needs further elaboration. However, in one passage of his book he draws inspiration from a quote from Paul Klee ('art does not reproduce the visible, it makes visible') to suggest that 'place marketing needs to move from derivative reproduction to revealing the unique, in the same way' (Murray 2001, 14, our emphasis). We share Murray's views that it is important to identify and build on distinctive local cultural resources for successful place branding and marketing, and that a place cannot be reduced to 'a product'. A city, for example, is a complex and multi-faceted entity, which can be described as:

a) an area defined by clear geographical boundaries, and endowed with certain natural characteristics;

b) an environment shaped by human intervention, comprising infrastructures, buildings, and a designed layout of streets, squares, public and open spaces;

c) a community of people, with particular social networks and dynamics (a society); 
d) a system of economic activities and relationships (an economy);

e) a natural environment, a built form, a society and an economy governed by an agreed set of principles and regulations resulting from the interaction between different political actors (a polity).

Our approach is based on the related disciplines of Cultural Mapping' and Cultural Planning. The latter is intended not as an attempt to plan culture, but rather as a culturally sensitive approach to different types of public policy, including place promotion and marketing (see Bianchini 1999a and 1999b).

The Cultural Mapping and Planning approach is an attempt to develop an alternative practice, which reveals the inadequacy of narrowly-based professional specialisations. These make it harder for policy-makers to capitalise creatively on the cultural resources of a place. Cultural Mapping - using a range of qualitative and quantitative methods to identify and describe local cultural resources - is thus an essential precondition for culturally sensitive place branding and marketing. The cultural resource of a place encompass the following elements:

$>$ arts and media activities and institutions;

> the cultures of youth, ethnic minorities and other 'communities of interest', including local festivals and other celebratory events;

$>$ the tangible and intangible heritage, including archaeology, gastronomy, local history, dialects and rituals;

$>$ the local 'image bank', which is defined in detail below;

$>$ the natural and built environment, including public and open spaces;

$>$ the diversity and quality of places where people socialise, including street markets, bars, clubs, cafes and restaurants;

$>$ local milieux and institutions for intellectual and scientific innovation, including Universities and private sector research centres;

$>$ the repertoire of local products and skills in the crafts, manufacturing and services (adapted from Bianchini, 1999b).

A related concept is that of mindscape, which is a structure of thinking about a place. An urban mindscape, for example, indicates something which exists between the physical landscape of a city and people's visual and cultural perceptions of it. Mindscape can also mean landscape of the mind. In this sense, a city's mindscape can be represented as an urban image bank. This consists of local and external images of a city, which are manifested in forms including the following:

$>$ media coverage;

$>$ stereotypes, jokes and conventional wisdom;

$>$ representations of a city in music, literature, film, the visual arts and other types of cultural production;

$>$ myths and legends;

$>$ tourist guidebooks;

$>$ city marketing and tourism promotion literature;

$>$ views of residents, city users and outsiders, expressed, for example, through surveys and focus groups (adapted from Bianchini 1999a).

Bloomfield (2006) highlights the importance of other components of urban mindscapes. These include: 
$>$ the special knowledge of environmentally sensitive groups like cyclists and city walkers, or of confidantes and gossip mongers like hairdressers and taxi drivers;

$>$ urban symbols and memorabilia, including religious and civic rituals and celebrations;

$>$ the institutional filters which operate as gatekeepers of collective memory, including local history museums and published histories of the city;

$>$ the spatial practices of different individuals and social groups.

A variety of methodologies may be necessary to audit these resources and their potential applications. For example, for the analysis of local and external perceptions of a place it may be appropriate to use content analysis or discourse analysis, as well as historical reconstructions of how the image of a locality in film, literature, music and other cultural forms has evolved.

\section{Planning culturally in practice}

The following are examples of how a Cultural Planning perspective has enabled local policy makers to see more clearly how the distinctive resources of a place can inform other aspects of local development and help in building a cohesive and shared identity and brand.

In the Southern Swedish city of Malmö, the Cultural Planning framework has been used to analyse the cultural and socio-spatial elements of the Western harbour area. The aim of this exercise was to formulate an inclusive cultural development and one where all sectors of the local community - from youth cultures to the immigrant cultures and the working class past of the city - could be harmoniously represented.

Malmö is today a cosmopolitan and multicultural city where high-tech and knowledgeintensive activities are slowly replacing the old, traditional industrial structure that since the 1960s had given it its 'working class' character. The integration of the Öresund region brought about by the building of the fixed link between Malmö and Copenhagen in 2000, are putting the city on the map along with advanced European 'second tier' centres such as Rotterdam, or Lille.

However, from the point of view of governance, such fast moving developments proved to be highly problematic coming as they did at a time of great change in the city. With $24 \%$ of its current population of 270,000 born abroad, Malmö is the most multiethnic city in Sweden, yet it has a rate of gainful employment below that of the national average, and continues to display a geographical and cultural segregation inherited from the industrial past.

These were the challenges confronted by the city, five years ago when a number of cultural mapping and 'visioning' exercises were conducted by policy-makers and planners in order to ground the specific culture and identity of Malmö into a new masterplan for a large area of the city situated in the Western harbour.

Here the work done by Lia Ghilardi in introducing the cultural planning approach resulted in bringing together, for the first time, teams of stakeholders from the different departments of the local authority, ranging from planning, to economic development, education and social integration, with voluntary sector organisations, 
artists, cultural practitioners, community representatives and developers in mechanisms such as the City Planning Forum. In particular, the 'Build Live Dialogue' (ByggaBoDialogen), a consultative platform, was put in place at the beginning of the masterplanning process to look into the cultural character of the Western harbour. This tool is still used today to arrive at a comprehensive vision for the city's new identity through cross-disciplinary work and participation.

This way of thinking is partly about letting go of traditional roles in order to utilise everyone's collective knowledge about place. The innovative element here is that of setting in motion a process of dialogue and collaboration between all those that have a stake in the future of the city before regeneration - and by extension, place marketing - take place.

In terms of identity-managing, the lesson that the city is learning is that today's Malmö is not the homogeneous city of forty years ago and that the top-down, grand Swedish narrative of planning by design has collapsed into a more fragmented, diverse set of visions, all of which have the same legitimacy over the city. An old top-down attitude is beginning to be replaced by a more adaptive approach to identity management involving more transparency, accountability and openness.

In practice this new way of thinking has resulted in actions ranging from 'the mapping of Malmö's talent' (looking at the cultural diversity of the city as an asset) to the creation of sustainable, cheap accommodation for young people (in partnership with the University) to the setting up of incubators for creative entrepreneurs and the provision of artists' studios in the Western harbour area. This in turn has contributed to making Malmö the preferred destination of young creatives, and of design and IT companies who now perceive the city as a 'cool' place to be.

Elsewhere in Sweden, the Kronoberg Region (also known as Södra Småland) is working to develop a pilot cultural planning strategy involving its six municipalities. The aim of the strategy is principally to raise the profile of the area following the disaster caused by Storm Gudrun, which hit the region in January 2005.

The starting point for the adoption of a Cultural Mapping and Planning approach to place marketing originated from the realisation that the storm had severely undermined the (perceived) USP of the area, which was the forest and country cottage holidaying. The following extract from a marketing brochure (2005) encapsulates the image of Södra Småland tourism and branding organisations wanted to disseminate for the purpose of attracting visitors and investors:

\section{Autumn in Småland}

"Bold brush strokes depict nature in warm red and golden-yellow tones. The air is crisp...

Life is good here. Let autumn be a time of enjoyment. Dinner for two at a country house. A weekend at a spa warms the soul. A round of golf will do the body good. The footbridge over the swamp in the nature reserve leads to adventure with the feeling of autumnal freedom for ever."

Småland - a wonderful place to live! 
This, rather romantic, perception of the region's identity was only part of the story, and it was only after the Storm that the local stakeholders began to take stock and challenged received assumptions about their locality. A series of seminars and workshop were organised and a full scale cultural mapping of the region was initiated (facilitated by Lia Ghilardi).

The mapping was underpinned by a set of principles.

- $\quad$ To understand people's needs, perceptions, aspirations (especially those of the young and women, who make up the majority of the local population)

- To challenge assumptions (e.g. 'this region is rural and isolated')

- $\quad$ To think more creatively about local resources (e.g. in what way can the young local student population contribute to local development and identity? What do the local entrepreneurs produce? How can these distinctive products be marketed within a broader regional identity?)

- $\quad$ To connect initiatives (e.g. by linking existing strategies and plans such as the local Cultural Strategy, the Economic Development Plan with tourism plans, housing developments and green transport initiatives)

- $\quad$ To turn weakness into strength (e.g. what other ways are there to add value to nature and the forest after the Storm?)

The mapping exercise became the catalyst for a process of cross-sector work and partnership building which has led to the setting up of a Södra Småland Stakeholders Group. The Group identified a set of targeted actions which include, among other, the creation of a Storm House (Stormens Hus).

This will be a high quality, carbon neutral new building made of sustainable materials and using local glass and wood products. The Stormens Hus will be both a visitors' attraction (with spaces where visitors can experience the sensorial effects of storms) and an education and research centre focused on the study of weather patterns and renewable sources of energy. The Hus will also be a place where local artists and creative industries entrepreneurs will be able to experiment with new digital and 3D technologies to create products and artefacts around the theme of nature and extreme weather.

The idea behind the Stormen Hus is that of using a catalyst project and the theme of renewable resources to set in motion a process of formulating a new and shared brand image for the region. In particular, the Stakeholders Group (which includes elected representatives from each municipality; cultural institutions; directors from the economic, cultural, tourism and place marketing organisations; voluntary sector organisations, and, crucially, locally based businesses such as IKEA), will also be in charge of formulating a ten year development plan for the whole of Södra Småland.

In the Swedish context, this integrated and holistic approach to local development represents an exciting new departure which will hopefully lead to fresh thinking in the field of sustainability in the social, economic and environmental spheres. 
The Swedish examples show that cultural mapping and planning can be useful tools in dealing with issues of change and disconnection between image and reality. They can help in identifying the distinctive features of a place and provide the methodological platform on which governments and stakeholders alike can build co-ordinated actions, investments, policies and communications. These innovative actions, however, to be successful, need to be connected with local needs and aspirations and, crucially, must be participatory, flexible and democratic in the way they administer and deliver their plans.

On this issue, the lesson learned from UK examples of use of Cultural Planning in reorienting the identity of places in need of regeneration show that places that did not 'stay true' to their history, social dynamics, economic background and distinctive heritage and urban features, tended to struggle with maintaining a new identity and brand over time while those that adopted a more 'organic' and joined up approach to identity building where more successful.

An example of the latter is perhaps Bristol where the Bristol Cultural Development Partnership (BCDP) was set up back in 1993. At the time the Bristol City Council's Cultural department, the Bristol Chamber of Commerce, local cultural organisations such as South West Arts (now Arts Council England South West), the University and local entrepreneurs came together to create and implement a medium to long term strategy for the improvement of the city.

The early 1990s were a difficult time for Bristol, with urban dereliction, poverty and social exclusion dominating the political agenda. Moreover, due to internal political divisions, the local Council had been until then unable to play a leading role in encouraging policy initiatives or strategy development. So when the idea of the Partnership was put on the table by the Chamber of Commerce, the Council had no choice but become a partner.

Since then, the BCDP has been influential in brokering the development of a series of ground-breaking projects, such as the annual short-film festival Brief Encounters, the creation of the Watershed Media Centre, and the Arnolfini contemporary art gallery, which has played a major role in the development of the harbour area and in rebuilding a new identity for the city. Today, though perhaps less prominently than previously, the Partnership continues to deliver projects (ranging from Bristol's bid for the 2008 European Capital of Culture to the Legible City public art plan), that maintain a brand for Bristol which is centred around the idea of creativity and innovation.

The lesson to be learned from Bristol is that 'organic' partnerships such as the BCDP, which start from a mapping of the local distinctive features and with a specific issue they want to tackle, can sometime succeed in meeting the needs of the local community while improving the image of the city as a whole.

\section{Conclusions}

Place branding and marketing must be seen as a truly creative rather than mechanical, formulaic processes. Policy-makers should not simply be exploiting cultural resources as tools for achieving non-cultural goals, but should let their own mindsets and assumptions be transformed by contact with the rich and ever changing detail of local culture. Let us consider briefly how place branding and marketing might develop by taking on board this 'culturally sensitive' approach. 
1) Place branding and marketing should be more holistic, interdisciplinary and lateral. This proposition suggests the need for greater collaboration between the policy-makers in our field and a range of other disciplines and skills, including those of urban historians, sociologists, anthropologists, environmentalists, artists, political scientists, and psychologists, for example. In other words, effective place branding and marketing strategies require regular teamwork and the overcoming of boundaries, both across different academic disciplines, and across the divides between the private, public and voluntary sectors. This process can start with a re-training of policy-makers and administrators so that they can acquire a broader knowledge of other disciplines involved in the understanding of how the fabric of a location functions (Bianchini and Ghilardi 85-87).

2) Place branding and marketing should be more innovative, original and experimental. This suggests the need for an R\&D approach, with a more extensive use of pilot projects, and greater consultation on the possible strategies to be developed, through workshops, ideas competitions and exhibitions, fora and discussion groups. These would involve citizens of different ages and social backgrounds, to identify and build on their mindscapes and imaginaries, and understand what are the factors which stimulate or hinder creativity and imagination (see, for example, Landry 2000, on the idea of the 'creative city').

3) Place branding and marketing should be more critical, challenging and questioning. The objective of these strategies should not be to construct a fake consensus by glossing over or denying the existence of real conflicts. Policies in our field can be much more effective when they openly acknowledge conflicts, divisions and problems and explore and problematise them further, in an attempt to find a real solution. Godela Weiss-Sussex (2006) argues that city branding and marketing should consider the complexity of a city's history as an asset. Urban mindscapes and imaginaries play an important role in cultural and historical continuity: in linking past, present and future.

4) Place branding and marketing strategies should be more people-centred and humanistic, by celebrating and giving voice to the imagination and the desires of different individuals and communities of interest within the city.

5) Lastly, place branding and marketing should be more 'cultured', knowledgeable and critically aware of traditions of cultural expression, by being rooted in research on the history, on the socio-economic realities, on the internal and external image, and on the cultural life and cultural representations of a particular locality. 


\section{References}

Bianchini, Franco. 1999a. The relationship between cultural resources and tourism policies for cities and regions. In Planning Cultural Tourism in Europe, eds. D. Dodd and A. van Hemel. Amsterdam: Boekmanstichting.

-1999b . Cultural planning for urban sustainability. In City and Culture.

Cultural Processes and Urban Sustainability, ed. Louise Nyström,, 34-51. Karlskrona: Swedish Urban Environment Council.

Bianchini, Franco, and Lia Ghilardi. 1997. Culture and Neighbourhoods: A Comparative Report. Strasbourg: Council of Europe Publishing.

Bloomfield, Jude and Franco Bianchini. 2004. Planning for the Intercultural City. Bournes Green: Comedia.

Bloomfield, Jude. 2006. "Researching the urban imaginary: resisting the erasure of places" in Weiss-Sussex, G. with Bianchini, F. (eds.) Urban Mindscapes of Europe Amsterdam: Rodopi.

Ghilardi, Lia. 2001. "Cultural Planning and Cultural Diversity" in Bennett, T. (ed) Differing Diversities: Cultural Policy and Cultural Diversity. Strasbourg: Council of Europe Publishing.

Ghilardi, Lia. 2006. "Identity by invocation or by design? How planning is conjuring up a new identity for Malmö" in Weiss-Sussex, G. with Bianchini, F. (eds.) Urban Mindscapes of Europe Amsterdam: Rodopi.

Landry, Charles. 2000. The Creative City. London: Earthscan.

Murray, Chris. 2001. Making Sense of Place: New Approaches to Place Marketing. Bournes Green: Comedia (in association with the International Cultural Planning and Policy Unit, De Montfort University, Leicester).

Weiss-Sussex, Godela. 2006. "Berlin literature and its use in the marketing of the 'New Berlin'", in Weiss-Sussex, G. with Bianchini, F. (eds.) (2006).

Weiss-Sussex, Godela with Bianchini, Franco (eds.) (2006) Urban Mindscapes of Europe Amsterdam, Rodopi.

\section{Description of the authors:}

Franco Bianchini is Professor of Cultural Policy and Planning at Leeds Metropolitan University. From 1992-2007 he was Reader in Cultural Planning and Policy and Course Leader for the MA in European Cultural Planning at De Montfort University in Leicester. His publications include Cultural Policy and Urban Regeneration: The West European Experience (with M. Parkinson, Manchester University Press, 1993), The Creative City (with C. Landry, Demos, 1995), Culture and Neighbourhoods: A Comparative Report (with L. Ghilardi, Council of Europe Press, 1997) Planning for the 
Intercultural City (with J. Bloomfield, Comedia, 2004) and Urban Mindscapes of Europe (co-edited by Godela Weiss-Sussex with Franco Bianchini, Amsterdam, Rodopi, 2006).

Contact details: Bianchin@aol.com

Tel. +441162704483

Lia Ghilardi is Director of Noema Research and Planning Ltd., an international consultancy specialising in cultural planning and place mapping. Following a career in urban sociology research and teaching, over the past fifteen years Lia has gained an international reputation through her work as facilitator and catalyst for high profile urban regeneration strategies based on local distinctiveness and community participation. In the UK she regularly works with Regional Development Agencies, civic leaders and the Arts Council. She also acts as advisor to the European Commission, The Council of Europe and EU networks on issues of culture and regeneration, identity, and diversity.

Contact details:

Lia Ghilardi, Noema Research and Planning

29 Arlingford Road, London, SW2 2SR

Tel: +442083556630

Email: lia.ghilardi@btinternet.com

www.noema.org.uk 